\title{
RETIREMENT CHOICES BY STATE AND LOCAL PUBLIC SECTOR EMPLOYEES: THE ROLE OF ELIGIBILITY AND FINANCIAL INCENTIVES
}

\author{
Leslie E. Papke \\ Working Paper 25436 \\ http://www.nber.org/papers/w25436 \\ NATIONAL BUREAU OF ECONOMIC RESEARCH \\ 1050 Massachusetts Avenue \\ Cambridge, MA 02138 \\ $\mathrm{n} / \mathrm{a}$
}

I thank Sita Slavov and conference participants at the NBER Conference on Incentives and Limitations of Employment Policies on Retirement Transitions for useful comments. I also thank seminar participants at Michigan State University, the Michigan Retirement Research Center and staff for their support of this project, as well as the staff at the Michigan Center for the Demography of Aging who have enabled my access to restricted data. Bryce S. Vanderberg provided excellent research assistance. All errors are my own. The views expressed herein are those of the author and do not necessarily reflect the views of the National Bureau of Economic Research.

NBER working papers are circulated for discussion and comment purposes. They have not been peer-reviewed or been subject to the review by the NBER Board of Directors that accompanies official NBER publications.

(C) 2019 by Leslie E. Papke. All rights reserved. Short sections of text, not to exceed two paragraphs, may be quoted without explicit permission provided that full credit, including ( $)$ notice, is given to the source. 
Retirement Choices by State and Local Public Sector Employees: The Role of Eligibility and Financial Incentives

Leslie E. Papke

NBER Working Paper No. 25436

$\mathrm{n} / \mathrm{a}$

JEL No. H72,H75,J26,J45,J82

\begin{abstract}
I analyze the effects of state public pension parameters on the retirement of public employees. Using a panel data set of public sector workers from 12 waves of the Health and Retirement Study, I model the probability of retirement as a function of pension wealth at early and normal retirement eligibility and Social Security coverage in the public sector job. I find that becoming eligible for early retirement, or receiving an early-out offer, significantly increases the probability of retiring. I do not find any effect of retirement wealth levels; instead the findings are consistent with the literature on default options in defined contribution plans. These findings suggest that state legislative action to affect retirement decisions and reduce future pension costs may be most effective operating through plan eligibility rules and early-out incentives.
\end{abstract}

Leslie E. Papke

Department of Economics

110 Marshall- Adams Hall

Michigan State University

East Lansing, MI 48824

PAPKE@MSU.EDU 
While defined contribution plans are now the norm in private employment, defined benefit plans remain dominant in the public sector. The additional costs incurred in closing a plan covering current workers are unaffordable for most states - instead recent legislative actions focus on changes that affect for new hires. The defined benefit structure has been maintained with a few exceptions - recent legislation created defined benefit hybrids or combinations with defined contribution plans for new hires that may reduce plan generosity but still maintain the pattern of defined benefit financial influences on retirement. In the period 2009 to 2012,44 states introduced changes in state pension plans for general employees and teachers to address long-term funding issues -- some states more than once. ${ }^{1}$ These changes include adjustments to generosity -- contribution rates, benefit reductions, and early retirement compensation rules -- as well as age/service eligibility criteria.

There is limited research to inform us on the relative importance of these parameters on the retirement choices of public sector workers. In particular, how does the structure of these plans - the eligibility age for early or normal retirement -- affect retirement behavior? Do earlyout offers increase the probability of retirement over and above existing incentives and the financial incentives of continued work? Given the substantial underfunding of many of these public pension plans, understanding the influences of plan generosity and eligibility requirements is critical for assessing plan solvency and evaluating the impact of these recent legislative changes. ${ }^{2}$ State and local government budget health depends on the cost of public sector defined

\footnotetext{
${ }^{1}$ For an overview see Snell (2012) and Martel and Petrini (2014). The National Conference of State Legislatures maintains a database of annual legislative actions at http://www.ncsl.org/research/fiscal-policy/pension-legislation-database.aspx.

${ }^{2}$ The substantial underfunding of these public plans has been well documented. In 2016, state pension fund debt experienced its $15^{\text {th }}$ annual increase since 2000, totaling $\$ 1.4$ trillion (Pew
} 
benefit plans and the retirement incentives they create for employees are important tools for managing the labor force Further, about three-quarters of public sector workers are also covered by Social Security so their retirement choices affect Social Security finances as well. More broadly, defined benefit payments in substantially underfunded plans have implications for intergenerational equity. For example, Backes et al (2016) estimate that on average across state plans, over 10 percent of current teachers' earnings are set aside for previously-accrued pension liabilities. As a public policy matter, it will be useful to understand the relative value participants place on aspects of these plans.

Unique features of public sector employment may allow us to compare separately the influences of eligibility for pension income, health insurance, and Social Security benefits because these eligibilities can occur at different ages. For example, many public sector workers have employer provided retiree health insurance in retirement that provided a bridge to Medicare for public sector workers who retire before 65 . In most previous research, age 65 is also the normal or full benefits retirement age for Social Security benefits. In contrast, most public sector workers can buy into group health insurance if they retire before 65 - effectively delinking the two influences at that important age. In addition, about 25 percent of state and local employees are not covered by Social Security and do not directly face its financial incentives and key eligibility ages. Studying the retirement behavior of public sector workers can inform us about the influence of Social Security and pension retirement incentives apart from health insurance eligibility.

Charitable Trust, 2018). Novy-Marx and Rauh, (2009) calculate substantially greater debt using economically appropriate discount rates. Giertz and Papke (2007) explore the interaction of state pension systems with state finances. 
In a defined benefit plan, retirement eligibility is a function of personal characteristics age, years of service, and some measure of salary -- so the data requirements to estimate the influence of eligibility separately from financial incentives are substantial. ${ }^{3}$ Fortunately, the Health and Retirement Study (HRS), the most comprehensive panel survey of pre-retirement respondents, includes a substantial number of public employees. In addition, HRS restricted pension data include individual-specific pension benefits and eligibility triggers. Thus, this paper directly complements Coile and Gruber's (2007) work to disentangle the effects of Social Security eligibility ages and financial incentives of continued work on private sector employee retirement in the HRS.

In this paper I explore the sensitivity of public sector employee retirement decisions to key features of state pension plans -- benefit generosity and early and normal retirement eligibility thresholds as well as the role of Social Security coverage. I use respondent-provided information on job history from 12 waves of the publicly available Health and Retirement Study (HRS) data to identify public employees and their retirement choice. I calculate respondent pension wealth and key eligibility ages using the HRS-provided Pension Estimation Program that uses restricted data on actual employment history linked to detailed plan information. I am able to identify an important subset of public employees - teachers - using restricted detailed industry and occupation codes. Finally, because differences in state policy toward public employees are of interest, I augment these data with the restricted geographic codes to identify state of residence. Using state of residence and job characteristics, I am able to determine if the employee is covered by Social Security and if further early retirement inducements from integrating with Social Security by leveling benefit payments are available.

\footnotetext{
${ }^{3}$ For an example using aggregate data, see Munnell et al (2015).
} 
The model underlying this analysis is a proportional hazard model with time-varying covariates that reflect state pension policy - vested pension wealth and eligibility for early retirement options, whether the public sector job is covered by Social Security, whether it includes employer-provided health insurance in retirement, as well as rich demographic characteristics. To preview the main results, I find that public employee retirement is responsive to program eligibility focal points - especially becoming eligible through meeting age and service requirements for the plan's early retirement benefit -- but not to pension wealth separately. Social Security coverage increases retirement probabilities for employees age 60-64, and coordinating with Social Security through leveling is an additional incentive to retire for this age group. Unlike previous findings on private employees, I do not find a statistically significant relationship between retirement and the gain in pension wealth from continued work. Special early-out provisions do appear to encourage earlier retirement, over and above the plan's early retirement provisions.

The next section presents some background on institutional features of public sector pension plans and reviews some related literature. Section 3 discusses the HRS panel of public employees and sources of pension plan information. Section 4 presents results using the sample of respondents who enter the sample while in public employment and retire from their public sector job. These results are compared to an HRS panel of non-public sector workers. The final section concludes.

\section{Background and Literature}

Most full-time state and local public employees participate in a defined benefit (DB) plan that offers normal retirement benefits at relatively early ages, and these plans vary widely across 
state and job descriptions in terms of pension generosity and early-out provisions. ${ }^{4}$ Typical public sector plans, for example, may allow for early retirement at age 55 and normal retirement at 60 conditional on a certain number of years of service. The retirement annuity is a function of a specific benefit rate for each year of service and the participant's final average salary over a specified period - often three years. For example, plans with a two percent replacement rate replace 60 percent of final average salary after 30 years of service. And plans also differ in eligibility thresholds - the age and service combination that determine early or normal retirement.

A second important dimension of difference across public sector jobs is Social Security coverage. Beginning in 1991, public employees who were not members of a qualifying state or local retirement system were generally required to have Social Security coverage. Federal law permits each public employer to decide which employees to cover, and the extent to which public employees are covered varies greatly from state to state. ${ }^{5}$ For example, the GAO (2010) reports that, based on Social Security Administration data (SSA), 98 percent of public employees are covered by Social Security in Vermont, but in Ohio only about three percent are covered. ${ }^{6}$ Further, there is variation in Social Security coverage among public employees working for the same employer. For example, Missouri's school districts have two separate retirement systems one for fulltime teachers and a separate one for fulltime non-teachers. The fulltime teachers do not generally have Social Security coverage while the fulltime non-teachers do. It is common, as in New Hampshire, to prohibit Social Security coverage for police and fire fighters who belong

\footnotetext{
${ }^{4}$ Beshears, Choi, Laibson, and Madrian (2011) illustrate a large amount of heterogeneity in replacement rates across DB plans even among employees with long tenure and discuss the role of DC plans in the public sector. Litwok and Papke (2014) simulate large differences across states in teacher pension accrual.

${ }^{5}$ See GAO (2010) Appendix II for the amount of covered and uncovered earnings by employees in each state. ${ }^{6}$ Employers may also choose to provide only Medicare coverage rather than both Social Security and Medicare. The SSA lacks basic data on which public employers have approved coverage and relies on public employers to comply with coverage agreements voluntarily (GAO, 2010).
} 
to a more generous plan than other public employees. Of course, public employees working in uncovered employment may still be eligible for Social Security benefits based on their spouse's or their own earnings in other, covered employment (GAO, 2003). ${ }^{7}$ In 2007, 73 percent of state and local government employees were covered by Social Security, accounting for $\$ 528$ billion of the $\$ 5$ trillion of covered wages (GAO, 2010). This leaves over five million public employees without Social Security coverage and seven states - California, Colorado, Illinois, Louisiana, Massachusetts, Ohio and Texas account for more than 75 percent of noncovered payroll (GAO, 2003). In particular, teachers do not participate in Social Security in 12 states. $^{8}$ As I discuss below, I am able to identify and expand the sample to include this important subgroup of public employees using restricted HRS occupation codes.

How to measure retirement is a subject of research itself. Gustman and Steinmeier (2000) discuss alternative measures using HRS data: by self-report of labor force status, by an hours-worked or salary measure, or leaving a job after a ten or 20 years. Maestas (2010) uses the original HRS cohort to study unretirement transitions directly. She compares alternative measures using hours of work and self-reports of retirement and finds that nearly 50 percent of retirees follow a nontraditional retirement path that follows partial retirement or unretirement. In what follows I use the panel structure of the HRS to identify retirement from the public sector

\footnotetext{
${ }^{7}$ SSA estimates that 95 percent of noncovered state and local employees become entitled to Social Security benefits as workers, spouses, or dependents. Note that Social Security has two provisions - the Government Pension Offset, which affects spouse and survivor benefits, and the Windfall Elimination Provisions which affects retired worker benefits. Both provisions reduce Social Security benefits for those who receive noncovered pension benefits. See Gustman, Steinmeier and Tabatabai (2013) for analysis of these provisions using HRS data.
}

${ }^{8}$ Morrill and Westall (2018) discuss the Social Security coverage status of teachers and provide analysis of retirement effects. For further discussion, see Doherty et al (2012). 
job - few of the public sector employees who retire over my sample period report any postretirement work.

Most previous research on the influence of retirement income - whether Social Security benefits or defined benefits pensions - finds significant effects on the timing of retirement from private sector employment. ${ }^{9}$ Coile and Gruber (2007) use HRS data to distinguish the differential impact of the Social Security eligibility structure - early retirement at age 62 or normal at (then) age 65 -- from the financial incentives of these benefits on male retirement in the private sector. They develop a forward-looking measure of retirement incentives, the "peak value," whereby individuals consider incentives to work in all future years. They define peak value as the difference between Social Security wealth (SSW) at its maximum expected value and SSW at today's value to measure incentives to continued work. Using two alternative measures of retirement - changes in earnings and self-reports of first exit after age 55 -- they find large effects at the key Social Security eligibility ages of 62 and 65, but they also find that retirement decisions respond negatively to accrual of retirement wealth with future work and positively to the level of retirement wealth. While the match to HRS restricted pension data is limited to about 60 percent for their sample, they conclude that private pension incentives have roughly similar effects. After comparing several incentive measures of future retirement income, they conclude that retirement decisions are more responsive to the entire future stream of retirement incentives than to the accrual in retirement wealth over the next year alone. In what follows, I adopt this forward-looking approach and construct the peak value measure for public pensions to capture the public pension incentive effects of working longer.

\footnotetext{
${ }^{9}$ Hurd (1990), and Friedberg and Webb (2005) provide summaries.
} 
Morrill and Westall (2018) use cross sectional data from the American Community Survey (ACS) to study the influence of Social Security coverage for public school teachers. ACS data on pension incentives are limited -- they approximate "theoretical eligibility" for retirement from the public sector job by comparing the age of the teacher with the pension plan's earliest full retirement age. They find strong evidence of higher rates of retirement among covered teachers at key Social Security eligibility ages with variation by marital status.

This literature includes studies of teacher-only retirement choices using administrative data from a handful of states (Costrell and Podgursky, 2009, Fitzpatrick, 2015, 2018). The primary limitation of this work is that administrative data do not include other factors that affect retirement well-being and retirement-related decisions - health, non-pension wealth, and spousal characteristics for example. Further, most public employees also have a second annuity - Social Security - so their valuation of benefits will likely differ from other public employees for whom this is the only source of a retirement annuity. But Asch, Haider, and Zissimopoulos (2005) examine retirement behavior of federal civil service workers using administrative data from the Department of Defense. These federal workers do not participate in Social Security and the authors find no "excess retirement" at age 62 or 65 . They estimate that civil service workers delay their retirement probability by four percent of the average retirement rate for every additional $\$ 10,000$ of expected pension wealth from working another year.

Shoven and Slavov (2014) focus on another important benefit in the public sector -employer-provided retiree health coverage -- on retirement decisions of federal, state, and local workers using the HRS - while controlling for a measure of pension wealth. As mentioned previously, employer provided retiree health insurance is common in the public sector, but relatively rare in the private sector. They examine retirement before the age of Medicare 
eligibility at 65 when retiree health coverage is most valuable and focus on the first full time self-report work exit over the roughly two-year period between waves. Their pension controls include the researcher-contributed supplement defined benefit and defined contribution wealth (Gustman, et al, 2012) and a set of DB pension status indicators from self-reports of early and normal retirement ages reported at entry into the HRS. They find that retiree health coverage raises the probability of stopping full time work over two years by 4.3 percentage points at ages 55-59 and by 6.7 percentage points at ages 60-64.

My analysis complements these previous studies by using some of the same controls but with individual measures of pension eligibility and wealth based on work history. I control for the same self-report of health insurance benefits, but am able to include the actual present value of pension wealth on the current job - the one that is changing with continued work - and the change in pension wealth from continuing to work another year at each age. I can control for the wealth effect of pensions as well as the early retirement incentives resulting from the pattern of benefit accrual with continued work. I use the person-specific eligibility for early retirement or normal retirement that isolates the eligibility effect from the wealth effect. Note that since I do not combine public employees with private employees, my method is not subject to selection on unobservables into public jobs that offer generous retirement benefits relative to wages and earlier retirement options with health insurance. But I do have concerns about unobservable individual heterogeneity possibly correlated with public job characteristics. While it is not possible to fully address these concerns with survey data, I do include initial job tenure and defined contribution balances at entry to control for heterogeneous preferences for long tenure and retirement. In addition, following Shoven and Slovov (2014), I exclude individuals with 
fewer than five years of service on the current job to reduce the possibility that individual job choice was motivated by health insurance.

\section{Data: Public employment in the HRS}

I use four comparable cohorts of the HRS - all the same age when they entered the HRS (age 51-56 in 1992, 1998, 2004, 2010) - that face different state or local defined benefit pension landscapes as they approach and enter retirement. Respondents are re-interviewed every other year after entering the survey. I make use of the panel structure of the HRS from 1992-2014 to compare initial and final self-reports of retirement with dates of public employment to find their final retirement from the public sector. Respondents indicate at their first interview whether they had ever worked for the federal, state, or local government and the start and end date of such jobs. In 2006, 2008, and 2010, the HRS added two new questions that determine if a respondent is currently employed by a government (question J720), and if so, what level of government (in 2008 only new interviewees and those who changed jobs were asked these questions). Going forward, this question repeats every six years. I determine public employment in other survey years by comparing the start and end date of any reported government job with the start and interview dates of their current job. I follow employment in each wave between 1992 and 2014 backward to earlier years that they remained in that same job. I identify job changes in and out of public employment across the waves (2 year intervals) and eventual retirement from the government job (if they retire from that job). So, the measure of retirement used here is based on self-reports with later wave confirmation that the respondent actually fully retired after leaving public employment. 
I focus on respondents who self-report as state or local public employees at their entry into the survey. ${ }^{10}$ Most of the data come from the RAND (version P) of the HRS with supplemental information from the RAND HRS Fat files. ${ }^{11}$ I supplement these data with three restricted data sources from the HRS: detailed industry and occupation, pension plan data, and geographic codes for state of residence. I use the industry and occupation data to identify finer job categories than are available in the public data. This is particularly relevant for teachers - an important category of public employment many of whom do not participate in Social Security.

Gustman et al. (2013) speculate that teachers are the most likely of non-Social Security covered respondents to indicate that they do not work for the government so by using the detailed industry data I can include them as public sector employees.

To examine the influence of pension wealth and eligibility for retirement under different provisions, I use detailed pension information that the HRS has matched to respondents to calculate the present value of pension wealth. These data come from four surveys of employers and from employer web sites (Fang et al, 2016). For respondents that have been matched to employer plans, the HRS Pension Estimation Program (PEP) calculates three types of present values of pension wealth for a respondent's current plan at any age: values that are available to participants who qualify for early retirement (ER), values available once the respondent qualifies for the plan's normal retirement age (NR), and vested deferred benefits that accumulate over time prior to any eligibility for retirement.

\footnotetext{
${ }^{10}$ Gustman, Steinmeier, and Tabatabai (2013) indentify underrerporting of public employment in the HRS. They find that too many respondents report not working for the government compared to those who report employment not covered by Social Security. I use a similar process to flag employment not covered by Social Security to investigate whether they should be flagged correctly as government employees. However, a full treatment of those respondents is outside the scope of this paper.

${ }^{11}$ For details, see https://www.rand.org/labor/aging/dataprod/fattable.html. The composition of the sample of public employees consists of the original HRS sample (46 percent), the War Babies/CODA sample (13 percent), the Early Baby Boomers (15 percent), and the Mid Baby Boomers (26 percent).
} 
While the early HRS pension employer surveys had low response rates, later surveys create more complete matches, particularly in the 2010 wave where much of the public plan information comes from employer websites. ${ }^{12}$ For public employees these data are primarily defined benefit (DB) plan parameters - benefit formulas and age and service requirements to meet early and normal retirement. I use the PEP that uses these parameters and Social Security earnings information to calculate present values of defined benefit pension wealth at ages 51 and older. The PEP data include defined contribution balances as well as required employee contributions to the DB plan.

Finally, I use restricted respondent geographic codes to identify the respondent's state of residence. This allows me to verify self-reports of Social Security coverage with other sources of Social Security coverage by employee type. The publicly available HRS data include estimates of Social Security wealth at key ages and an indicator of receipt, but these Social Security benefits are not necessarily due to the current job. The Wisconsin Legislative Council (2013) reports fund name, type of employee covered, as well as Social Security coverage among other features of 87 large public pension plans. ${ }^{13}$ I match these coverage data by state of residence and employee type. Public employees who are also covered by Social Security may have another option available for early retirement - Social Security leveling. Clark at al (2017) summarize state annuity options for Social Security leveling for the 20 out of 85 large statemanaged public pension plans that cover teachers, state, and/or local employees. ${ }^{14}$ Another way public pension benefits feature of public retirements is Social Security leveling. Leveling is

\footnotetext{
12 Coile and Gruber (2007) use the first five waves of the HRS and report a 60 percent match rate with private pension data.

${ }^{13}$ The HRS restricted pension data do not identify whether the respondent is covered by Social Security unless the pension benefit must be coordinated with Social Security benefits. The HRS restricted data agreements do not allow use of both the restricted geographic codes and restricted Social Security earnings records.

14 The Wisconsin Legislative Council (2013) describes these 85 plans in bi-annual reports.
} 
the option to get a higher pension benefit before claiming Social Security, but after claiming, the pension benefit drops. Leveling is a policy variable that could be used to encourage or discourage retirement.

\section{Methods and Results}

The sample consists of state and local public employees employed in the public sector at their baseline interview. It is natural, then, since they all start in the same employment state to model their retirement in duration framework. The model underlying the analysis is a proportional hazard model with time-varying covariates, which can be written as

$$
h\left(t ; \boldsymbol{Z}_{i t}\right)=\operatorname{base}(t) \exp \left(\boldsymbol{Z}_{i t} \boldsymbol{\beta}\right)
$$

where the $\boldsymbol{Z}_{i t}$ include covariates that may change over time. As shown in Jenkins (1995), the proportional hazards model leads to a binary response model for retirement at age $t$ conditional on not having retired prior to age $t$. The resulting response probability has the complementary $\log$ - log form, which is different from both logit and probit in that it is the cumulative distribution function of an asymmetric distribution. The implied model relates the probability of retirement from a public sector job, conditional on not having retired prior to that age, to pension options available for that individual, adjusting for covariates that factor into the retirement decision such as health status, Social Security participation, and employer-provided health insurance in retirement.

To be more specific, the conditional probability that public employee $i$ retires at age $t$ is

$$
\begin{aligned}
\operatorname{Pr}\left(\text { retire }_{i t}=\right. & 1 \mid \cdot) \\
& =F\left(\beta_{0}+\beta_{1} \text { eligible }_{i t}+\beta_{2} \text { pvwealth }_{i t}+\beta_{3} \text { peakdiff }_{i t}+\beta_{4} \text { DC@entry }_{i t}\right. \\
& \left.+\beta_{5} \text { SScov }_{i t}+\beta_{6} \text { SSelig }_{i t}+\beta_{7} \text { SSlev }_{i t}+\boldsymbol{X}_{i t} \boldsymbol{\beta}_{7}+\beta_{8} \text { wave }_{t}+\boldsymbol{a g e}_{\boldsymbol{i t}} \boldsymbol{\beta}_{\mathbf{9}}\right)
\end{aligned}
$$


where retire is a binary indicator for whether individual $i$ retires at age $t$. Because retirement is taken as the final state in the analysis, it takes on zero followed by one if a person is observed to retire. The function $F(u)$ for argument $u$ is the complementary log-log cumulative distribution function:

$$
F(u)=1-\exp (-\exp (u))
$$

which is used in a pooled binary response estimation.

The vector $\boldsymbol{a g} \boldsymbol{e}_{\boldsymbol{i t}}$ represents a vector of age dummies, whose coefficients can be turned into estimates of the baseline hazard. Employee retirement options are captured by eligible, that is, the employee may be eligible for early retirement or normal retirement. ${ }^{15}$ The present value of pension wealth, pvwealth, is the present value of early retirement benefits if eligible, normal-age retirement benefits if eligible, or the present value of vested deferred benefits if not yet eligible for either early or normal retirement. The peak value concept, peakdiff, is the forward-looking measure of the incentive to continued work developed by Coile and Gruber $(2000,2007)$. It measures the difference between pension wealth at its maximum expected value and pension wealth at today's value. The HRS PEP includes defined contribution balances for the small set of employees who have them in addition to their defined benefit plan. I include in indicator for whether they have balances at entry into the survey to control for individual saving propensity. Demographic variables are included in $X . S S C o v$ is the indicator for participation in Social Security and SSelig is an interaction between the coverage variable and age 62, when early retirement from Social Security is possible. I adjust the standard errors by clustering at the household level.

\footnotetext{
${ }^{15}$ I set the early retirement dummy variable to zero once normal-age retirement eligibility is reached.
} 
Many of the dollar amounts (measured in 2012 dollars) in the data are zero (before pension benefits are vested, for example) and there are extreme values for total assets and pension wealth. I use the log-modulus transformation (John and Draper, 1980) to dampen extreme values without having to use a special convention for zero values. ${ }^{16}$ For values of pension wealth away from zero, the log modulus transformation is very similar to taking the log. Therefore, when interpreting the results, it makes sense to change the log modulus by something like 0.01 (a one percent increase in pension wealth) or 0.10 (a ten percent increase in pension wealth). In the latter case, this is the same as dividing the coefficient by 10 . But because the model is nonlinear, I will report the average partial effects of changing each variable, but these, too, must be multiplied by the desired change on the log modulus.

The baseline hazard, estimated with only age dummies (ages 51-72 and older) using 13,455 observations, is pictured in Figure 1. As Coile and Gruber (2007) note regarding Social Security, the underlying structure of public pension plans - early and normal retirement eligibility ages -- play a critical role in determining retirement decisions. There is a small peak at age 55; that is, conditional on working to 55, the probability of retiring at this age is about .08. The largest spike occurs around ages 60 and 62 - the probability of exiting during this interval conditional on not having exited is .25 . Table 1 illustrates the early and normal retirement eligibility ages for the respondents that are calculated by the PEP program. That is, 1,294 respondents have an early retirement option, and based on their eventual years of service 16.69 percent of them (216) were eligible for early retirement at age 55, and 17.54 percent of them at age 56. The most common eligibility age is 60 in the sample, with 15.73 percent attaining normal retirement at that age.

\footnotetext{
16 The transformation is $g(x)=\operatorname{sign}(x) \log (|x|+1)$ where $\operatorname{sign}(x)=1, x>0, \operatorname{sign}(x)=-1, x<0$, and $\operatorname{sign}(x)=0, x=0$. The function is strictly increasing and continuously differentiable, even at $x=0$.
} 
Table 2 presents summary statistics for the data used in this analysis -- the teacher category is the only industry or occupation category I summarize here. The sample size for entry characteristics is 3,248 and 1,460 for characteristics measured in the retirement wave that I eventually observe. Sixty-two percent of the sample is female, and 28 percent enter employed as teachers. Twelve percent report being in fair or poor health and nine percent have spouses that are already retired. Eighty-five percent of the sample is covered by Social Security and 24 percent have access to leveling. At retirement, 19 percent are eligible for early retirement benefits, and 40 percent are eligible for normal retirement. Nine percent of the sample report being offered an early-out package over and above their plan's early retirement provisions.

Table 3 presents the maximum likelihood estimation results of the complementary loglog response probability. I report only the marginal effects of interest, but also have included age and wave dummies, a female dummy, race, education, marital status, fair or poor health selfreported status, whether a spouse is retired, broad occupation dummies, as well as the teacher indicator, tenure and defined contribution balances at survey entry in the current job, and earnings and assets transformed as discussed earlier. These are estimated on a sample that includes missing data indicators. ${ }^{17}$

The marginal effects of the dummy variables are interpreted as changes in the probability of retiring from one's public sector job. The results are consistent across all five specifications so I discuss the estimates from the most complete model in column 5. Two personal characteristics - having a spouse who is already retired and being in fair or poor health -increase the probability of retirement by .029 and .057 respectively. They are highly statistically significant. Employer provision of retiree health insurance encourages retirement for the two

\footnotetext{
17 The complete cases hazards use between 3,093 and 4,830 observations. I note in the text where the results differ. These results are available from the author.
} 
young age categories highlighted and these estimates are precisely measured. This health insurance increases the probability of retiring by .05 for those age 55 to 59 and by .04 for those 60 to 64 , holding pension eligibility and Social Security coverage fixed. Social Security coverage does affect the probability of retirement for those 60 to 64 by about .05 , about the same magnitude as access to health insurance in retirement. The effect of the Social Security leveling variable is statistically insignificant when it is included for the two key age groups.

I define the early retirement and normal retirement indicators to be mutually exclusive. In plans without an early retirement option programmed in the PEP, the normal retirement indicator is on and stays on once the normal retirement eligibility is reached. I estimate that becoming eligible for early retirement increases the probability of retiring by .042 and this estimate is statistically significant at conventional levels. Becoming eligible for normal retirement also increases the probability of retiring but this estimate has a p-value of .09 . I estimate a positive as expected, but very small, statistically insignificant impact of retirement wealth on retirement itself - whether at early or normal retirement.

The peakdiff coefficient measures the effect of forward-looking incentives - the increase in retirement wealth from continuing to work. Recall, this is measured as the difference between pension wealth in the current wave (the present value of deferred vested benefits calculated in the PEP at that age) and the maximum value of pension wealth, transformed as described previously. There appears to be no effect of these financial incentives apart from becoming eligible for retirement in these models. In other results that use complete cases of the data (not reported here) I find a statistically significant but economically very small effect -- a ten percent higher future value of retirement benefits is estimated to reduce the probability of retirement by .0006 . 
The HRS PEP is programed with the typical structure of the public sector pension plans but not with special one-time offers to encourage retirement. The HRS publicly available data includes questions about this potentially important labor management tool and I include a general indicator for being offered an early out package as well as the indicator interacted with the two pre-retirement age groups of interest. These offers are estimated to increase the probability of retirement the most for the youngest employees -- by .096 regardless of age, and by. 048 for those age 55 to 59 . The estimate for those ages $60-64$ is .071 but is not statistically significant.

As discussed previously, it is in the public sector where defined benefit plans play an important role now and in future retirement decisions and labor management choices - defined contribution plans now dominate in private sector employment. But for completeness and comparison purposes, I estimate similar hazard models on respondents in the HRS that I did not flag as public employees at entry - these respondents are privately employed or (a small number of) self-employed. I estimate the models on the private sector employees separately - in a model that combined public and private sectors, a test that the pension variables have a similar effect for the two types of employees was rejected with a p-value of .0002. Summary statistics are provided in Table 4, and hazard model estimates in Table 5. I summarize the interesting differences here.

The private sample is only 40 percent female compared with my public sample of 60 percent, includes fewer non-white respondents, a higher percentage in poor health, and lower percentages with post-high school education. The influence of having a retired spouse is estimate to be twice as large at that in the public sector - increasing the retirement probability by .061. The effect of health insurance in retirement is similar for both samples - increasing 
retirement probabilities for the two pre-retirement age groups by about .04 . The most interesting differences are with respect to early retirement eligibility and Social Security coverage and the findings are consistent with older retirement ages observed in the private sector. Becoming eligible for early retirement in one's private sector job is estimated to reduce the probability of retiring by .036 , holding pension wealth and Social Security coverage fixed. Unlike in the public sector estimates, there is a statistically significant effect of wealth at early retirement but the estimated effect is small - ten percent higher pension wealth increases the probability of retiring by .002 .

The effect of Social Security, while positive and large generally (.13), is negative and statistically significant for the younger age group - I estimate that Social Security coverage reduces the probability of retiring by .04 for those 55-59 and increases it by .025 for those 60-64. Finally, an early out offer increases the probability of first retirement from a private sector job by .126 for those age 55-59, a much larger effect than the .048 for the comparable age group in the public sector.

\section{Discussion and Conclusion}

Evidence presented here suggests that public employee retirement is responsive to program eligibility focal points - in particular becoming eligible for the plan's early retirement benefit through one's age and years of service. But I find no evidence that pension wealth or future pension incentives influence retirement separately. This finding is consistent with the literature on default options in 401(k) plans documented by Choi at al (2002,2003). Defaults established in these $401(\mathrm{k})$ plans affect plan participation and individual savings rates, for example, perhaps because employees view them as implicit suggestions. The results in this 
paper suggest that the same may true for defined benefit plans in the public sector. It is possible that if becoming eligible for early retirement is perceived as reference point, deviations from that point may be psychologically uncomfortable. ${ }^{18}$ This effect appears particularly strong in the public sector results in comparison with the opposite impact in the private sector results.

While personal circumstances like poor health have larger economic effects, state and local governments, or school districts, can encourage retirement by offering retiree health insurance, and offering an early out package. Or, conversely, they may choose to retain employees longer by eliminating retiree health insurance (which, unlike pension benefits in most state, are not constitutionally protected) or by changing the age/service combination for these suggested retirement focal points. These findings do suggest that state legislative action to affect retirement decisions and reduce future pension costs may be most effective operating through plan eligibility rules and early-out incentives rather than plan generosity. Similarly, these findings suggest that legislators may be able to reduce plan generosity without much affecting retirement decisions.

Some caveats of this work should be mentioned. I am unable to control for Social Security wealth that is known to influence retirement along with pensions, although I do control for earnings and coverage (Coile and Gruber, 2007). Further, this work focuses on the decision to fully retire from the public sector - that is, the employees do not return to work elswhere. Only about five percent of this sample report later part-time employment following retirement from their public sector job. Given the use of final average salary in the defined benefit annuity, part-time work would have to be done under a special arrangement like a DROP plan, or with another employer. In future work it may be possible to identify states where DROP plans are

${ }^{18}$ See Samuelson and Zeckhauser (1988) for a discussion of status quo bias. 
used. It is possible that different factors influence the decision to work part-time and future waves of the HRS may assist in the study of unretirement in the public sector. 


\section{References}

Asch, B., S.J. Haider, J. Zissimopolos, (2005), "Financial incentives and retirement: evidence from federal civil service workers," Journal of Public Economics 89, 427-440.

Backes, B., D. Goldhaber, C. Grout, C. Koedel, S. Ni, M. Podgursky, P.B. Xiang, and Z. Xu (2016). "Benefit or Burden? On the Intergenerational Inequity of Teacher Pension Plans," Educational Researcher 45(6), 367-377.

Beshears, J. J. Choi, D. Laibson, and B. Madrian (2011), Behavioral Economics Perspectives on Public Sector Pension Plans, Journal of Pension Economics and Finance 10(2), 315-336.

Brown, K. (2009), "Teacher pensions and retirement in California. Paper presented at the National Center on Performance Incentives National Conference, Vanderbilt University, February.

Choi, J.J. , D. Laibson, B.C. Madrian, and A. Metrick,(2002) "Defined Contribution Pension Plans: Plan Rules, Participant Decisions, and the Path of Least Resistance," in James M. Poterba, ed., Tax Policy and the Economy, Vol. 16, Cambridge, MA: MIT Press, 67-113.

---- “Optimal Defaults,” (2003), The American Economic Review, Vol. 93, No. 2, May, 180-185.

Clark, R.L., R.G. Hammond, M.S. Morrill, D. Vanderweide, (2017) "Annuity Options in Public Pension Plans: The curious case of Social Security leveling," NBER Working Paper No. 23,262, March.

Coile, C.C., and J. Gruber, (2007) "Future Social Security Entitlements and the retirement decision," Review of Economics and Statistics 89, 234-46.

Costrell, R.M., and J. B. McGee, (2010), "Teacher pension incentives, retirement behavior, and potential for reform in Arkansas, Education Finance and Policy 5(4), 492-518.

Costrell, R. M. and M. Podgursky, (2009), "Peaks, cliffs, and valleys: The peculiar incentives in teacher retirement systems and their consequences for school staffing," Education Finance and Policy 4(2), 175-211.

Doherty, Kathryn M., Sandi Jacobs, and Trisha M. Madden. (2012). "No One Benefits: How Teacher Pension Systems are Failing Both Teachers and Taxpayers." National Council on Teacher Quality, Washington D.C.

Fang, C., A. Butchart, H. Stolyarova, M. Nolte, B. Peticolas, (2016), "Pension Estimation Program Users Guide," HRS website: V. 3.1 April.

Fitzpatrick, M.D., (2015), "How much are public school teachers willing to pay for their retirement benefits?” American Economic Journal: Economic Policy 7(4), 165-188. 
Friedberg, L. and A. Webb, (2005), "Retirement and the evolution of pension structure,” Journal of Human Resources 40, 281-308.

Furgeson, J., R. Strauss, and W. Vogt, (2006), “The effects of defined benefit pension incentives and working conditions on teacher retirement decisions." Education Finance and Policy 1(3), 316-48.

Giertz, J.F and L.E. Papke, (2007), "Pension Funding and State Government Finances: Back in the Black or Trouble Ahead?", National Tax Journal 60, 305-323, June.

Government Accounting Office, (2010), "Social Security Administration: Oversight needed to ensure accurate treatment of state and local employees," GAO-10-938.

Gustman, A.L., Steinmeier, T.L., (2000), "Retirement Outcomes in the Health and Retirement Study," NBER Working Papke \# 7588.

Gustman, A.L., Steinmeier, T.L., Tabatabai, N., (2010), Pensions in the Health and Retirement Study, Harvard University Press.

Gustman , A.L., Steinmeier, T.L., Tabatabai, N., (2012), Enhancing Pension Data Files for Modeling Health and Retirement and for the HRS User Community: 1992 to 2006. Available at: http://hrsonline.isr.umich.edu.

Gustman, A.J., T.L. Steinmeier, and N. Tabatabai, “The Social Security Windfall Elimination and Government Pension Offset Provisions for Public Employees in the Health and Retirement Study," NBER Working Paper 19724, December 2013.

Health and Retirement Study, Public Use Dataset, 2016. Produced and Distributed by the University of Michigan with funding from the National Institute on Aging. Available at: http://hrsonline.isr.umich.edu.

Hurd, M. (1990), "Research on the elderly: economic status, retirement, and consumption and savings, "Journal of Economic Literature 28(2), 565-637.

Jenkins, S. P.,(1995), "Easy Estimation Models for Discrete-time Duration Models," Oxford Bulletin of Economics and Statistics 57: 1, 129-138.

John and Draper, (1980), Journal of the Royal Statistical Society, Applied Statistics Series C.

Kim, D., C. Koedel, S. Ni, M. Podgursky, W. Wu, "Pensions and Late-Career Teacher Retention," July 2017.

Litwok, D. and L.E. Papke (2013), "Interstate Differences in Pension Vesting Rules and K-12 Teacher Experience," Proceedings of the National Tax Association, November 21-23.

Maestas, N., (2010) "Back to Work: Expectations and Realizations of Work after Retirement." Journal of Human Resources 45(3), 718-748. 
Martel, L. and A. Petrini, (2014) "Pensions and Retirement Plan Enactments in 2013 State Legislatures," National Conference of State Legislatures.

Morrill, M. S. and J. Westall, (2018). "Social Security and Retirement Timing: Evidence from a National Sample of Teachers," draft, September 29.

Munnell, A., J-P Aubry, J. Hurwitz, and L. Quinby, (2011), "Can State and Local Pensions Muddle Through," Center for Retirement Research, March, Number 15.

Munnell, A.H., J-P Aubry, and G. T. Sazenbacher, (2015), "Recruiting and Retaining HighQuality State and Local Workers: Do Pension Matter?" Center for Retirement Research, January, Number 1.

Novy-Marx, R. and J. D. Rauh, (2009), “The Liabilities and Risks of State-Sponsored Pension Plans, Journal or Economic Perspectives, Vol. 23, No. 4, Fall, pp. 191-210.

Samuelson, W. and R. Zeckhauser, (1988), "Status Quo Bias in Decision Making," Journal of Risk and Uncertainty, March. 7-59.

Shoven, J.B. and S.N. Slavov, (2014) "The role of retiree health insurance in the early retirement of public sector employees," Journal of Health Economics 38, pp. 99-108.

Snell, R., (2012), "State Pension Reform, 2009-2011," National Conference of State Legislatures, March.

The Pew Center on the States, (2010), “The trillion dollar gap: Unfunded state retirement systems and the roads to reform," February.

The Pew Charitable Trusts, (2018), “The State Pension Funding Gap: 2016, April.

Wisconsin Legislative Council (2013), “2012 Comparative Study of Major Public Employee Retirement Systems."

Wooldridge, J.M., (2010), Econometric Analysis of Cross Section and Panel Data, MIT Press. 
Figure 1:

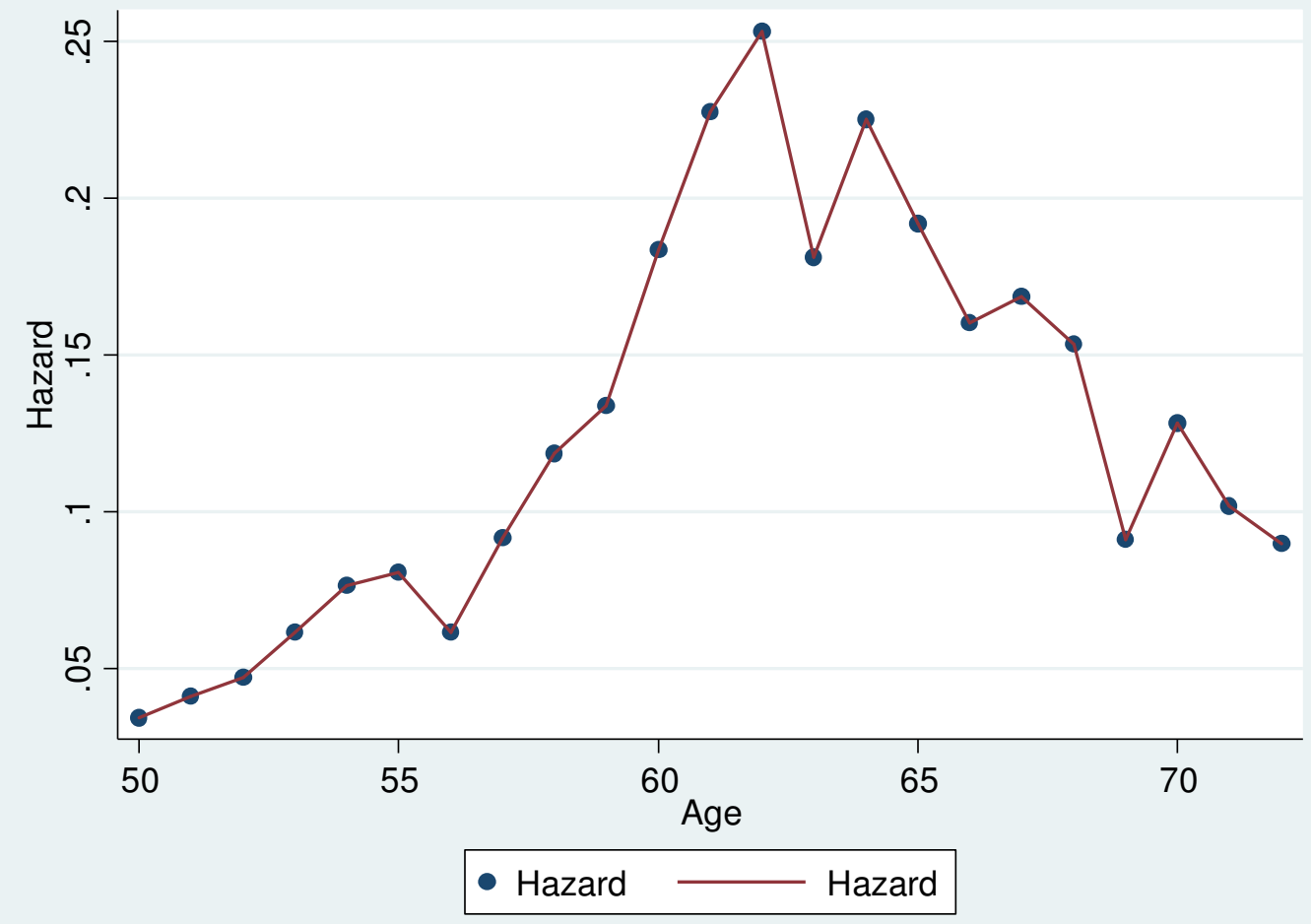


Table 1: Early and Normal Retirement Eligibility Ages for Public Employees in the HRS: Frequency and Percent of Sample of Public Employees at Entry

\begin{tabular}{|l|l|l|l|l|}
\hline Age & $\begin{array}{l}\text { Early Retirement } \\
\text { Eligibility } \\
\text { Frequency }\end{array}$ & $\begin{array}{l}\text { Early Retirement } \\
\text { Eligibility } \\
\text { Percent }\end{array}$ & $\begin{array}{l}\text { Normal } \\
\text { Retirement } \\
\text { Eligibility } \\
\text { Frequency }\end{array}$ & $\begin{array}{l}\text { Normal } \\
\text { Retirement } \\
\text { Eligibility } \\
\text { Percent }\end{array}$ \\
\hline 51 & 38 & 2.94 & 23 & 1.65 \\
\hline 52 & 50 & 3.86 & 27 & 1.94 \\
\hline 53 & 48 & 3.71 & 34 & 2.44 \\
\hline 54 & 35 & 2.70 & 36 & 2.59 \\
\hline 55 & 216 & 16.69 & 104 & 7.47 \\
\hline 56 & 227 & 17.54 & 89 & 6.39 \\
\hline 57 & 108 & 8.35 & 55 & 3.95 \\
\hline 58 & 77 & 5.95 & 61 & 4.38 \\
\hline 59 & 75 & 5.80 & 46 & 3.30 \\
\hline 60 & 97 & 7.50 & 219 & 15.73 \\
\hline 61 & 99 & 7.65 & 196 & 14.08 \\
\hline 62 & 55 & 4.25 & 121 & 8.69 \\
\hline 63 & 38 & 2.94 & 92 & 6.61 \\
\hline 64 & 24 & 1.85 & 31 & 2.23 \\
\hline 65 & 27 & 2.09 & 116 & 8.33 \\
\hline 66 & 15 & 1.16 & 77 & 5.53 \\
\hline 67 & 16 & 1.24 & 27 & 1.94 \\
\hline 68 & 12 & 0.93 & 12 & 0.86 \\
\hline Obs. & 1,294 & & 1,392 & \\
\hline & & & \\
\hline
\end{tabular}

Source: Author's calculations using the HRS Pension Estimate Program (Feng et al, 2016). Note: These are empirical eligibility ages based on an individual's age/service history. 
Table 2. Summary Statistics for Public Employees

\begin{tabular}{|l|l|l|l|l|}
\hline & Mean & Std. Dev. & Min & Max \\
\hline Age & 55.09 & 4.53 & 50 & 84 \\
\hline Female & 0.62 & 0.49 & 0 & 1 \\
\hline Married & 0.72 & 0.45 & 0 & 1 \\
\hline Spouse retired & 0.09 & 0.29 & 0 & 1 \\
\hline Tenure & 14.62 & 10.06 & 12.6 & 48.5 \\
\hline White & 0.71 & 0.45 & 0 & 1 \\
\hline Black & 0.22 & 0.41 & 0 & 1 \\
\hline Hispanic & 0.10 & 0.29 & 0 & 1 \\
\hline Fair/poor health & 0.12 & 0.33 & 0 & 1 \\
\hline Health Ins. In ret. & 0.43 & 0.50 & 0 & 1 \\
\hline Less than HS & 0.10 & 0.3 & 0 & 1 \\
\hline High School & 0.23 & 0.42 & 0 & 1 \\
\hline Some College & 0.21 & 0.41 & 0 & 1 \\
\hline College & 0.17 & 0.37 & 0 & 1 \\
\hline College + & 0.30 & 0.46 & 0 & 1 \\
\hline Teacher & 0.28 & 0.45 & 0 & 1 \\
\hline Earnings (\$2012) & 49,356 & 39,309 & 0 & 506,098 \\
\hline SS coverage & 0.85 & .36 & 0 & 1 \\
\hline SS leveling & 0.24 & .43 & 0 & 1 \\
\hline & & & & $1,779,000$ \\
\hline $\begin{array}{l}\text { PV_Vested/Deferred } \\
\text { pension wealth }\end{array}$ & 262,000 & 246,000 & 0 & 1 \\
\hline Eligible ER & 0.19 & 0.39 & 0 & 1 \\
\hline Eligible NR & 0.40 & 0.49 & 0 & $1,779,000$ \\
\hline $\begin{array}{l}\text { PV_ER (\$2012) } \\
\text { pension wealth }\end{array}$ & 194,000 & 251,000 & 0 & 1 \\
\hline $\begin{array}{l}\text { PV_NR (\$2012) } \\
\text { pension wealth }\end{array}$ & 197,000 & 270,000 & 0 & \\
\hline Offered EO & 0.09 & 0.28 & 0 & \\
\hline & & & & \\
\hline Source: Aun & & & & 1,000 \\
\hline
\end{tabular}

Source: Author's calculations from the HRS Waves 1-12.

Notes: The values in the top panel are measured at a respondent's entry into the survey with 3,248 observations. The values in the lower panel are measured in the year of retirement with 1,460 observations. . SS = Social Security, EO = offered early out, NR = normal retirement, 
Table 3. Impact of Retirement Options on the Probability of Retiring from the Public Sector

\begin{tabular}{|c|c|c|c|c|c|}
\hline & (1) & (2) & (3) & (4) & (5) \\
\hline $\begin{array}{l}\text { Spouse } \\
\text { retired }\end{array}$ & $\begin{array}{l}.028^{* * *} \\
(.009)\end{array}$ & $\begin{array}{l}.028^{* * *} \\
(.009)\end{array}$ & $\begin{array}{l}.028^{* * * *} \\
(.009)\end{array}$ & $\begin{array}{l}.028^{* * *} \\
(.010)\end{array}$ & $\begin{array}{l}.029^{* * * *} \\
(.009)\end{array}$ \\
\hline Poor health & $\begin{array}{l}.057^{* * * *} \\
(.010)\end{array}$ & $\begin{array}{l}.057^{* * * *} \\
(.010)\end{array}$ & $\begin{array}{l}.058^{* * * *} \\
(.010)\end{array}$ & $\begin{array}{l}.058^{* * * *} \\
(.010)\end{array}$ & $\begin{array}{l}.057^{* * * *} \\
(.010)\end{array}$ \\
\hline $\begin{array}{l}\text { Ret. Health } \\
\text { Ins. }\end{array}$ & & $\begin{array}{l}. .007 \\
(.013)\end{array}$ & $\begin{array}{l}.009 \\
(.013) \\
\end{array}$ & $\begin{array}{l}-.008 \\
(.013)\end{array}$ & $\begin{array}{l}-.009 \\
(.013)\end{array}$ \\
\hline $\begin{array}{l}\text { Ret. HI } \\
55-59 \\
\end{array}$ & & $\begin{array}{l}.062^{* * *} \\
(.022)\end{array}$ & $\begin{array}{l}.059^{* *} \\
(.022) \\
\end{array}$ & $\begin{array}{l}.059^{* *} \\
(.021)\end{array}$ & $\begin{array}{l}.059^{* * *} \\
(.021)\end{array}$ \\
\hline $\begin{array}{l}\text { Ret. HI } \\
60-64\end{array}$ & & $\begin{array}{l}.051^{*} \\
(.020)\end{array}$ & $\begin{array}{l}.045^{*} \\
(.020)\end{array}$ & $\begin{array}{l}.042^{*} \\
(.020)\end{array}$ & $\begin{array}{l}.043^{*} \\
(.020)\end{array}$ \\
\hline Elig ER & & & $\begin{array}{l}.041^{*} \\
(.017)\end{array}$ & $\begin{array}{l}.042^{*} \\
(.017)\end{array}$ & $\begin{array}{l}.042^{*} \\
(.017)\end{array}$ \\
\hline ER Wealth & & & $\begin{array}{l}.002 \\
(.002)\end{array}$ & $\begin{array}{l}.002 \\
(.002)\end{array}$ & $\begin{array}{l}.002 \\
(.002)\end{array}$ \\
\hline Elig NR & & & $\begin{array}{l}.034 \\
(.022) \\
\end{array}$ & $\begin{array}{l}.038 \\
(.022) \\
\end{array}$ & $\begin{array}{l}.038 \\
(.022) \\
\end{array}$ \\
\hline NR Wealth & & & $\begin{array}{l}.002 \\
(.002)\end{array}$ & $\begin{array}{l}.002 \\
(.002)\end{array}$ & $\begin{array}{l}.001 \\
(.002)\end{array}$ \\
\hline Peakdiff & & & $\begin{array}{l}.001 \\
(.003)\end{array}$ & $\begin{array}{l}.001 \\
(.001)\end{array}$ & $\begin{array}{l}.001 \\
(.001)\end{array}$ \\
\hline SS Cov & & & & $\begin{array}{l}.016 \\
(.014)\end{array}$ & $\begin{array}{l}-.017 \\
(.014) \\
\end{array}$ \\
\hline $\begin{array}{l}\text { SS Cov } \\
55-59\end{array}$ & & & & $\begin{array}{l}-.001 \\
(.012)\end{array}$ & $\begin{array}{l}-.001 \\
(.019) \\
\end{array}$ \\
\hline $\begin{array}{l}\text { SS Cov } \\
60-64\end{array}$ & & & & $\begin{array}{l}.063^{*} \\
(.025)\end{array}$ & $\begin{array}{l}.064^{*} \\
(.025)\end{array}$ \\
\hline $\begin{array}{l}\text { SS Leveling } \\
55-59\end{array}$ & & & & $\begin{array}{l}.007 \\
(.012)\end{array}$ & $\begin{array}{l}.007 \\
(.012)\end{array}$ \\
\hline $\begin{array}{l}\text { SS Leveling } \\
60-64\end{array}$ & & & & $\begin{array}{l}-.011 \\
(.010)\end{array}$ & $\begin{array}{l}-.011 \\
(.010)\end{array}$ \\
\hline Offered EO & & & & & $\begin{array}{l}.096^{* *} \\
(.031)\end{array}$ \\
\hline $\begin{array}{l}\text { Offered EO } \\
55-59\end{array}$ & & & & & $\begin{array}{l}-.048^{* *} \\
(.016)\end{array}$ \\
\hline $\begin{array}{l}\text { Offered EO } \\
60-64\end{array}$ & & & & & $\begin{array}{l}-.025 \\
(.019)\end{array}$ \\
\hline Obs. & 12,285 & 12,285 & 12,285 & 12,257 & 12,257 \\
\hline
\end{tabular}

Source: Author's calculations from the HRS Waves 1-12.

Notes: Marginal effects are reported above standard errors clustered at the household level. Marginal effects for wealth variables are reported at eligibility. Personal/job characteristic controls include age and wave dummies, a female dummy, race and ethnicity, marital status, fair/poor health indicator, occupation dummies, education dummies, tenure and defined 
contribution balances at entry, and total assets. Total assets and pension wealth variables are transformed via the logmodulus transformation in estimation. SS = Social Security, ER = early retirement, $\mathrm{NR}=$ normal retirement, $\mathrm{EO}=$ offered early out. ${ }^{*} \mathrm{p}<.05,{ }^{* *} \mathrm{p}<.01,{ }^{* * *} \mathrm{p}<.001$. 
Table 4. Summary Statistics for Private Sector Employees

\begin{tabular}{|c|c|c|c|c|}
\hline & Mean & Std. Dev. & Min & $\operatorname{Max}$ \\
\hline Age & 55.16 & 4.56 & 50 & 89 \\
\hline Female & 0.40 & 0.49 & 0 & 1 \\
\hline Married & 0.72 & 0.45 & 0 & 1 \\
\hline Spouse retired & 0.07 & 0.25 & 0 & 1 \\
\hline Tenure & 13.86 & 11.68 & 10.7 & 66.4 \\
\hline White & 0.76 & 0.43 & 0 & 1 \\
\hline Black & 0.17 & 0.38 & 0 & 1 \\
\hline Hispanic & 0.07 & 0.26 & 0 & 1 \\
\hline Fair/poor health & 0.15 & 0.35 & 0 & 1 \\
\hline Health Ins. In ret. & 0.31 & 0.46 & 0 & 1 \\
\hline Less than HS & 0.20 & 0.40 & 0 & 1 \\
\hline High School & 0.32 & 0.47 & 0 & 1 \\
\hline Some College & 0.24 & 0.43 & 0 & 1 \\
\hline College & 0.13 & 0.33 & 0 & 1 \\
\hline College + & 0.11 & 0.31 & 0 & 1 \\
\hline Teacher & 0.001 & 0.04 & 0 & 1 \\
\hline \multicolumn{5}{|l|}{ Earnings (\$2012) } \\
\hline SS coverage & 0.94 & .023 & 0 & 1 \\
\hline $\begin{array}{l}\text { PV_Vested/Deferred } \\
\text { pension wealth } \\
(\$ 2012)\end{array}$ & 157,000 & 241,000 & 0 & $2,362,000$ \\
\hline Eligible ER & 0.09 & 0.29 & 0 & 1 \\
\hline Eligible NR & 0.13 & 0.34 & 0 & 1 \\
\hline $\begin{array}{l}\text { PV_ER (\$2012) } \\
\text { pension wealth }\end{array}$ & 141,000 & 238,000 & & $2,417,000$ \\
\hline $\begin{array}{l}\text { PV_NR (\$2012) } \\
\text { pension wealth }\end{array}$ & 117,000 & 239,000 & 0 & $2,176,000$ \\
\hline Offered EO & 0.05 & 0.22 & 0 & 1 \\
\hline
\end{tabular}

Source: Author's calculations from the HRS Waves 1-12.

Notes: The values in the top panel are measured at a respondent's entry into the survey with 9,980 observations. The values in the lower panel are measured in the year of retirement with 5,799 observations. . SS $=$ Social Security, $\mathrm{EO}=$ offered early out, $\mathrm{NR}=$ normal retirement, $\mathrm{ER}$ $=$ early retirement. 
Table 5. Impact of Retirement Options on the Probability of Retiring from the Private Sector

\begin{tabular}{|c|c|c|c|c|c|}
\hline & (1) & (2) & (3) & (4) & (5) \\
\hline $\begin{array}{l}\text { Spouse } \\
\text { retired }\end{array}$ & $\begin{array}{l}.066^{* * *} \\
(.004)\end{array}$ & $\begin{array}{l}.064^{* * *} \\
(.004)\end{array}$ & $\begin{array}{l}.062^{* * *} \\
(.004)\end{array}$ & $\begin{array}{l}.058^{* * *} \\
(.004)\end{array}$ & $\begin{array}{l}.061^{* * * *} \\
(.004)\end{array}$ \\
\hline Poor health & $\begin{array}{l}.055^{* * *} \\
(.003)\end{array}$ & $\begin{array}{l}.056^{* * * *} \\
(.013)\end{array}$ & $\begin{array}{l}.057^{* * * *} \\
(.003)\end{array}$ & $\begin{array}{l}.050^{* * *} \\
(.003)\end{array}$ & $\begin{array}{l}.053^{* * * *} \\
(.003)\end{array}$ \\
\hline $\begin{array}{l}\text { Ret. Health } \\
\text { Ins. }\end{array}$ & & $\begin{array}{l}.013 \\
(.013)\end{array}$ & $\begin{array}{l}.009 \\
(.013)\end{array}$ & $\begin{array}{l}.006 \\
(.012)\end{array}$ & $\begin{array}{l}.001 \\
(.013)\end{array}$ \\
\hline $\begin{array}{l}\text { Ret. HI } \\
55-59 \\
\end{array}$ & & $\begin{array}{l}.053^{* *} \\
(.018)\end{array}$ & $\begin{array}{l}.042^{*} \\
(.017) \\
\end{array}$ & $\begin{array}{l}.042^{* *} \\
(.016)\end{array}$ & $\begin{array}{l}.042^{*} \\
(.018) \\
\end{array}$ \\
\hline $\begin{array}{l}\text { Ret. HI } \\
60-64\end{array}$ & & $\begin{array}{l}.045^{* * *} \\
(.016)\end{array}$ & $\begin{array}{l}.034^{*} \\
(.016)\end{array}$ & $\begin{array}{l}.035^{*} \\
(.015)\end{array}$ & $\begin{array}{l}.043^{*} \\
(.017)\end{array}$ \\
\hline Elig ER & & & $\begin{array}{l}-.034^{* * * *} \\
(.008)\end{array}$ & $\begin{array}{l}-.037^{* * * *} \\
(.007)\end{array}$ & $\begin{array}{l}-.036^{* * *} \\
(.009)\end{array}$ \\
\hline ER Wealth & & & $\begin{array}{l}.015^{* * *} \\
(.001)\end{array}$ & $\begin{array}{l}.015^{* * *} \\
(.001)\end{array}$ & $\begin{array}{l}.015^{* * * *} \\
(.001)\end{array}$ \\
\hline Elig NR & & & $\begin{array}{l}.058^{* * *} \\
(.021)\end{array}$ & $\begin{array}{l}.036 \\
(.020)\end{array}$ & $\begin{array}{l}.036 \\
(.021)\end{array}$ \\
\hline NR Wealth & & & $\begin{array}{l}.001 \\
(.004)\end{array}$ & $\begin{array}{l}.007 \\
(.004)\end{array}$ & $\begin{array}{l}.006 \\
(.004)\end{array}$ \\
\hline Peakdiff & & & $\begin{array}{l}-.0001 \\
(.001)\end{array}$ & $\begin{array}{l}-.003 \\
(.002)\end{array}$ & $\begin{array}{l}-.001 \\
(.001)\end{array}$ \\
\hline SS Cov & & & & $\begin{array}{l}.121^{* * *} \\
(.005)\end{array}$ & $\begin{array}{l}.132^{* * *} \\
(.005)\end{array}$ \\
\hline $\begin{array}{l}\text { SS Cov } \\
55-59\end{array}$ & & & & $\begin{array}{l}-.064^{* * * *} \\
(.037)\end{array}$ & $\begin{array}{l}-.173^{* * *} \\
(.037)\end{array}$ \\
\hline $\begin{array}{l}\text { SS Cov } \\
60-64\end{array}$ & & & & $\begin{array}{l}-.098^{* * * *} \\
(.033)\end{array}$ & $\begin{array}{l}-.107^{* * *} \\
(.036)\end{array}$ \\
\hline Offered EO & & & & & $\begin{array}{l}.116^{* * *} \\
(.022)\end{array}$ \\
\hline $\begin{array}{l}\text { Offered EO } \\
55-59\end{array}$ & & & & & $\begin{array}{l}.010^{* * *} \\
(.019)\end{array}$ \\
\hline $\begin{array}{l}\text { Offered EO } \\
60-64\end{array}$ & & & & & $\begin{array}{l}-.017 \\
(.014)\end{array}$ \\
\hline Obs. & 55,798 & 55,798 & 55,798 & 55,798 & 51,206 \\
\hline
\end{tabular}

Notes: Marginal effects are reported above standard errors clustered at the household level. Marginal effects for wealth variables are reported at eligibility. Personal/job characteristic controls include age and wave dummies, a female dummy, race and ethnicity, marital status, fair/poor health indicator, occupation dummies, education dummies, tenure and defined contribution balances at entry, and total assets. Total assets and pension wealth variables are 
transformed via the logmodulus transformation in estimation. $\mathrm{SS}=$ Social Security, ER = early retirement, $\mathrm{NR}=$ normal retirement. ${ }^{*} \mathrm{p}<.05,{ }^{* *} \mathrm{p}<.01,{ }^{* * *} \mathrm{p}<.001$. 